\title{
GAME EDUKASI MATEMATIKA BERBASIS ANDROID
}

\author{
Septi Fajarwati' ${ }^{1)}$, Riswati ${ }^{2)}$, Tri Astuti ${ }^{3)}$ \\ 1,2,3Fakultas Ilmu Komputer, Universitas Amikom Purwokerto \\ 1email: septi.semangat45@amikompurwokerto.ac.id \\ 2email: riswatiwati98@gmail.com \\ 3email: triastuti@amikompurwokerto.ac.id
}

\begin{abstract}
The process of teaching and learning activities implemented at SD Negeri 3 Tanjunganom still uses conventional methods. Even though the school has provided android facilities for students to support learning, this has not been utilized properly by teachers including mathematics teachers, so that many students have difficulty understanding mathematics, especially in the sub-material of building cubes and blocks. This is evidenced by the low average value obtained when compared to other subject matter. The purpose of this research is to create learning media for mathematics education games to build android-based cubes and blocks. So it is hoped that it can help teachers in learning in class and is also expected to make it easier for students to understand the material, especially the sub-material of building cubes and blocks. Applications that are made are developed using the Multimedia Development Life Cycle (MDLC) method, namely drafting, designing, collecting materials, manufacturing, testing, and distribution. The result of this research is that mathematics education game has been successfully created with android based sub-material building blocks and cubes. The results of the Beta test, which involved 30 respondents, obtained an average of $88 \%$ strongly agree, meaning that the application of math education games to build cubes and blocks is made attractive and easy to use by students of SD Negeri 3 Tanjunganom, especially class $V$.
\end{abstract}

Keywords: Mathematics, Educational Games, Android

Abstrak: Proses kegiatan belajar mengajar yang diterapkan di SD Negeri 3 Tanjunganom masih menggunakan cara konvensional. Meskipun pihak sekolah telah menyediakan fasilitas android untuk siswa guna menunjang pembelajaran, akan tetapi hal tersebut tidak dimanfaatkan dengan baik oleh para guru termasuk guru matematika, sehingga banyak siswa yang mengalami kesulitan dalam memahami pelajaran matematika khususnya pada sub materi bangun ruang kubus dan balok. Hal tersebut dibuktikan dengan nilai rata-rata yang diperoleh masih rendah jika dibandingkan dengan muatan pelajaran lainnya. Tujuan dari penelitian ini adalah untuk membuat media pembelajaran game edukasi matematika bangun ruang kubus dan balok berbasis android. Sehingga diharapkan dapat membantu guru dalam pembelajaran di kelas dan juga dapat memudahkan siswa dalam memahami materi terutama sub materi bangun ruang kubus dan balok. Aplikasi yang dibuat dikembangkan dengan metode Multimedia Development Life Cycle (MDLC) yaitu Pengonsepan, Perancangan, Pengumpulan Bahan, Pembuatan, Pengujian, dan Distribusi. Hasil dari penelitian ini adalah telah berhasil dibuat game edukasi matematika sub materi bangun ruang kubus dan balok berbasis android. Hasil pengujian Beta test yang melibatkan 30 responden diperoleh rata-rata $88 \%$ sangat setuju, artinya bahwa aplikasi game edukasi matematika bangun ruang kubus dan balok yang dibuat menarik dan mudah digunakan oleh siswa SD Negeri 3 Tanjunganom khususnya kelas $V$.

Kata kunci: Matematika, Game Edukasi, Android

\section{PENDAHULUAN}

Guru mempunyai peran yang sangat penting sebagai sumber belajar, karena berkaitan erat dengan penguasaan materi pelajaran. Proses pembelajaran matematika di kelas akan ditentukan oleh penguasaan 
guru terhadap materi itu sendiri dan kreativitas guru pada saat kegiatan belajar mengajar. Sehingga kurangnya pemahaman dari seorang guru terhadap materi pelajaran dapat menyebabkan ketidaksempurnaan proses pembelajaran di kelas. Untuk menghindari hal tersebut, guru dapat menyusun strategi pembelajaran dengan memanfaatkan berbagai media dalam bentuk yang lebih menarik. Pemanfaatan media pembelajaran yang interaktif dapat membantu guru dalam penyampaian materi, agar siswa dapat memahami materi yang sedang disampaikan dan mempermudah pemahaman siswa. Menurut Wibawanto (2017) media pembelajaran merupakan media kreatif yang digunakan dalam memberikan materi pelajaran kepada anak didik sehingga proses belajar mengajar lebih efektif, efisien dan menyenangkan.

Proses kegiatan belajar mengajar yang diterapkan di SD Negeri 3 Tanjunganom, Kecamatan Rakit, Kabupaten Banjarnegara masih menggunakan cara konvensional. Meskipun pihak sekolah telah menyediakan fasilitas android untuk siswa guna menunjang pembelajaran, akan tetapi hal tersebut tidak dimanfaatkan dengan baik oleh para guru termasuk guru matematika, sehingga banyak siswa yang mengalami kesulitan dalam memahami pelajaran matematika khususnya pada sub materi bangun ruang kubus dan balok. Hal tersebut dibuktikan dengan nilai rata-rata yang diperoleh masih rendah jika dibandingkan dengan muatan pelajaran lainnya, yaitu diperoleh data bahwa nilai rata-rata pelajaran matematika adalah 79,2, Pendidikan Agama 86.2, Pendidikan KewargaNegaraan 85.5, Bahasa Indonesia 84, Ilmu Pengetahuan Alam 84, Ilmu Pengetahuan Sosial 85, Olahraga 86, Bahasa Jawa 86.75, Dawet Ayu (Mulok) 86, dan Seni Budaya (SBDP) adalah 88,3.
Berdasarkan permasalahan di SD Negeri 3 Tanjunganom, diperlukan suatu inovasi dalam pembelajaran matematika agar siswa lebih tertarik dan semangat dalam belajar. Salah satu alternatifnya adalah dengan memanfaatkan game sebagai media pembelajaran edukasi.

Perkembangan industri game sebagai sarana pendidikan di Indonesia sudah berkembang dengan pesat. Dalam game, pendidikan diberikan lewat praktek atau pembelajaran dengan praktek. Seperti yang diungkapkan oleh Novaliendry (2013) bahwa game edukasi digunakan sebagai salah satu media pembelajaran yang memiliki pola pembelajaran learning by doing. Pola pembelajaran yang dilakukan dapat melalui tantangan-tantangan yang ada dalam permainan game ataupun faktor kegagalan yang dialami pemain, sehingga mendorong pemain untuk tidak mengulangi kegagalan dalam tahap berikutnya. Berdasarkan pola yang dimiliki oleh game tersebut, pemain dituntut untuk belajar sehingga dapat menyelesaikan permasalahan yang ada. Status game, instruksi, dan tools yang disediakan oleh game akan membimbing pemain secara aktif untuk menggali informasi sehingga dapat memperkaya pengetahuan dan strategi saat bermain. Selanjutnya Pramuditya, Noto, \& Purwono (2018) menyatakan bahwa game edukasi bisa menjadi media pembelajaran yang mengasikkan, menyenangkan, memiliki rangkaian dan meyebabkan kecanduan. Selain itu, menurut Nikensasi, Kuswardayan, \& Sunaryono (2012) game edukasi merupakan salah satu tema permainan yang berusaha memberikan nilai edukasi dalam sebuah permainan sehingga permainan yang awalnya hanya berfungsi sebagai media penghibur, akhirnya juga dapat digunakan sebagai media pembelajaran atau pelatihan. 
Dari uraian di atas, game edukasi dapat menjadi salah satu solusi untuk memecahkan permasalahan yang ada di SD Negeri 3 Tanjunganom sebagai media pembelajaran matematika yang inovatif.

\section{METODE PENELITIAN}

Rancangan penelitian ini dapat dilihat pada Gambar 1 sebagai berikut :

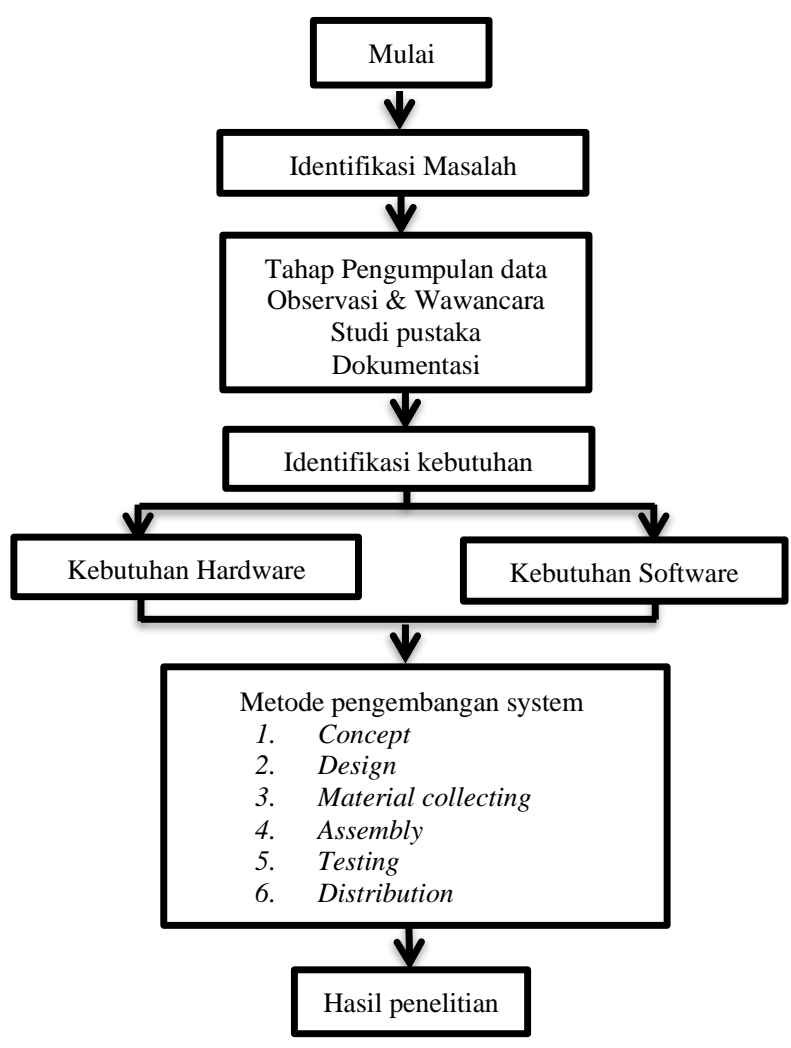

Gambar 1. Diagram Alur Penelitian

Gambar 1 merupakan rancangan penelitian yang akan ditempuh untuk mencapai tujuan penelitian yaitu dari seluruh proses penelitian yang diawali dengan mulai sampai dengan selesai.

Identifikasi masalah merupakan tahap awal melakukan sebuah penelitian untuk mempelajari peristiwa yang dipilih oleh peneliti dalam mengidentifikasi masalah ada beberapa tahapan diantaranya yaitu menentukan rumusan masalah, menentukan batasan masalah, menentukan tujuan penelitian, dan menentukan manfaat penelitian.

Tahap pengumpulan data adalah proses yang digunakan untuk mengumpulkan data-data yang digunakan pada tahap ini peneliti melakukan observasi, wawancara, dokumentasi, dan studi pustaka.

Identifikasi kebutuhan system adalah mengidentifikasi apa yang dibutuhkan dalam proses produksi yang terdiri dari kebutuhan perangkat keras (Hardware) maupun perangkat lunak (Software).

Metode pengembangan system yang digunakan untuk mengembangkan system pada penelitian ini adalah Multimedia Development Life Cycle (MDLC) versi Luther Sutopo yang terdiri dari enam tahap, yaitu pengonsepan (concept), perancangan (design), pengumpulan materi (material collecting), pembuatan (assembly), pengujian (testing), dan pendistribusian (distribution) (Binanto, 2010). 


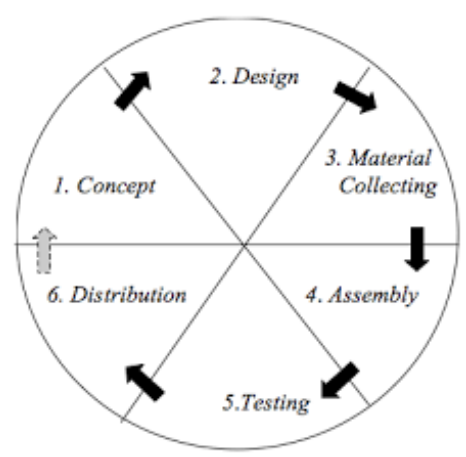

Gambar 2. Tahap Pengembangan Multimedia

Gambar 2 merupakan tahap dalam Multimedia Development Life Cycle (MDLC).

\section{HASIL DAN PEMBAHASAN}

Dalam penelitian ini mengggunakan konsep penelitian dengan metode MDLC (Multimedia Development Life Cycle) (Binanto, 2010) yang terdiri dari 6 tahap yaitu: pengonsepan (Concept), perancangan (Design), pengumpulan materi (Material Collecting), pembuatan (Testing), pengujian (Assembly) dan pendistribusian (Distribution). Penjelasan tahap dan analisis hasil penelitian ini adalah sebagai berikut:

Concept (Pengonsepan). Game ini didesain untuk siswa kelas V Sekolah Dasar khususnya di SD Negeri 3 Tanjunganom, Kecamatan Rakit, Kabupaten Banjarnegara.
Game ini berisi tentang pembelajaran tematik kurikulum 2013 sub tema 3 pembelajaran 1 mata pelajaran matematika dengan materi bangun ruang kubus dan balok.

Design (Perancangan). Design merupakan pembuatan rancangan untuk menggambarkan alur dari setiap scene, kebutuhan material atau bahan untuk game kubus dan balok. Pada tahap ini penulis menggunakan storyboard dan struktur navigasi yang digunakan untuk menggambarkan desain tampilan dan menggambarkan isi dari tiap-tiap layout dengan mencantumkan semua objek multimedia. Untuk penentuan tautan dari layout satu ke layout yang lain.

Tabel 1. Storyboard

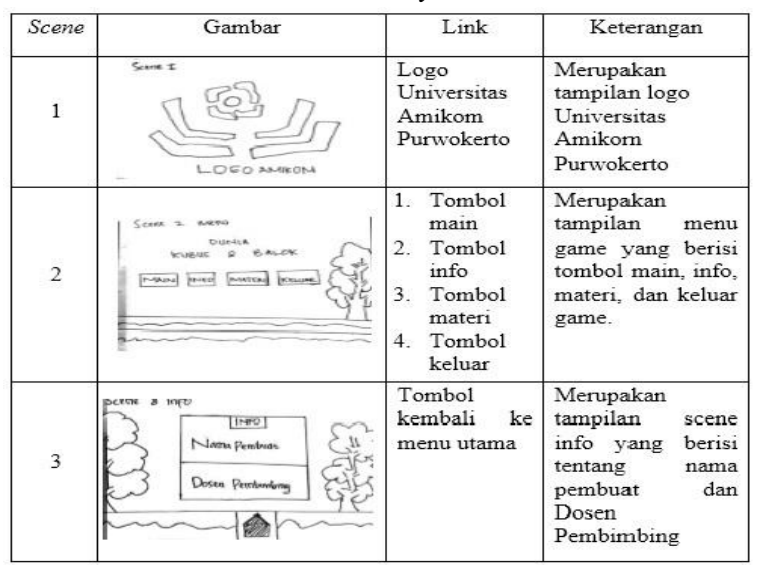

Material Collecting (Pengumpulan Bahan). Bahan yang dikumpulkan pada tahap ini yaitu gambar, suara, teks dan bahan pendukung lainnya. Sebagian besar gambar 
dibuat dengan Adobe Photoshop dan asset yang ada di Unity. Material collecting yang diperlukan untuk pembuatan aplikasi disajikan pada Tabel 2 sebagai berikut:

Tabel 2. Pengumpulan Bahan

\begin{tabular}{|c|c|c|c|c|}
\hline No & Nama & Ukuran & Type & Keterangan \\
\hline 1 & $\begin{array}{l}\text { Scene awal: Logo } \\
\text { Amikom }\end{array}$ & $227 \mathrm{~kb}$ & png & www.amikompurwokerto.ac.id \\
\hline 2 & $\begin{array}{l}\text { Scene Menu: } \\
\text { 1. Background } \\
\text { 2. Judul game } \\
\text { 3. Main } \\
\text { 4. Materi } \\
\text { 5. Keluar } \\
\text { 6. Backsound } \\
\text { 7. Button Sound }\end{array}$ & $\begin{array}{l}73 \mathrm{~kb} \\
24 \mathrm{~kb} \\
6.0 \mathrm{~kb} \\
4.97 \mathrm{~kb} \\
4.77 \mathrm{~kb} \\
4.3 \mathrm{mb} \\
2.1 \mathrm{mb}\end{array}$ & $\begin{array}{l}\text {.png } \\
\text {.png } \\
\text {.png } \\
\text {.png } \\
\text {.png } \\
\text { Mp3 } \\
\text { WAV }\end{array}$ & $\begin{array}{l}\text { Dibuat menggunakan Adobe } \\
\text { Photoshop } \\
\text { Dibuat menggunakan Adobe } \\
\text { Photoshop } \\
\text { Dibuat menggunakan Adobe } \\
\text { Photoshop } \\
\text { Dibuat menggunakan Adobe } \\
\text { Photoshop } \\
\text { Dibuat menggunakan Adobe } \\
\text { Photoshop } \\
\text { https://www.youtube.com } \\
\text { https://www.youtube.com }\end{array}$ \\
\hline
\end{tabular}

Assembly (Pembuatan). Tahap pembuatan game edukasi matematika kubus dan balok adalah sebagai berikut:

Pembuatan asset-aset game pada Adobe Photoshop antara lain :Pembuatan karakter anak-anak yang ditunjukkan pada Gambar 3 dan Pembuatan game pada unity $3 D$

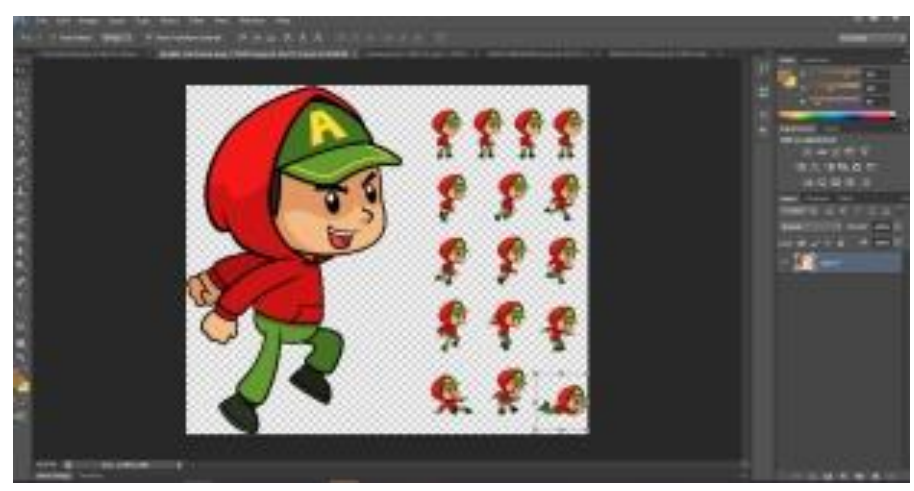

Gambar 3. karakter anak-anak

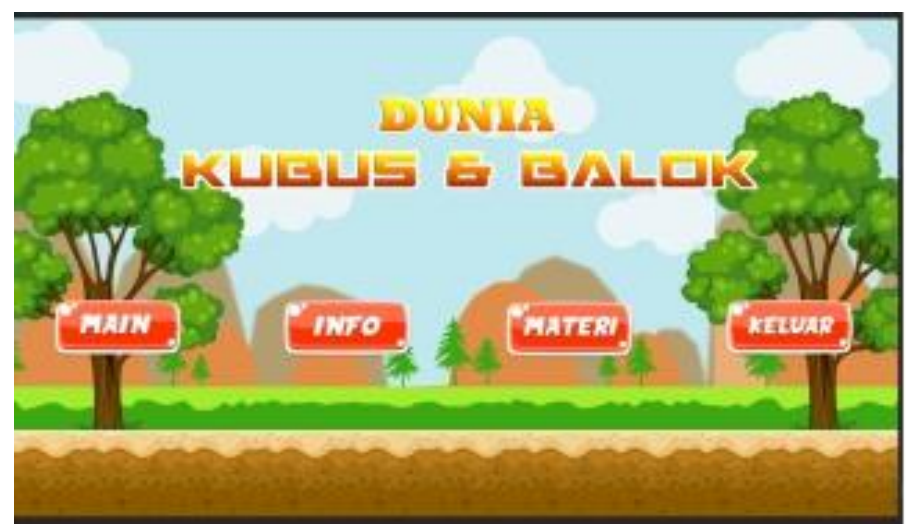

Gambar 4. Tampilan menu utama 
Gambar 4 adalah tampilan dari menu utama game edukasi dunia kubus dan balok pada halaman ini terdapat tombol menu, main, info, materi, dan keluar.

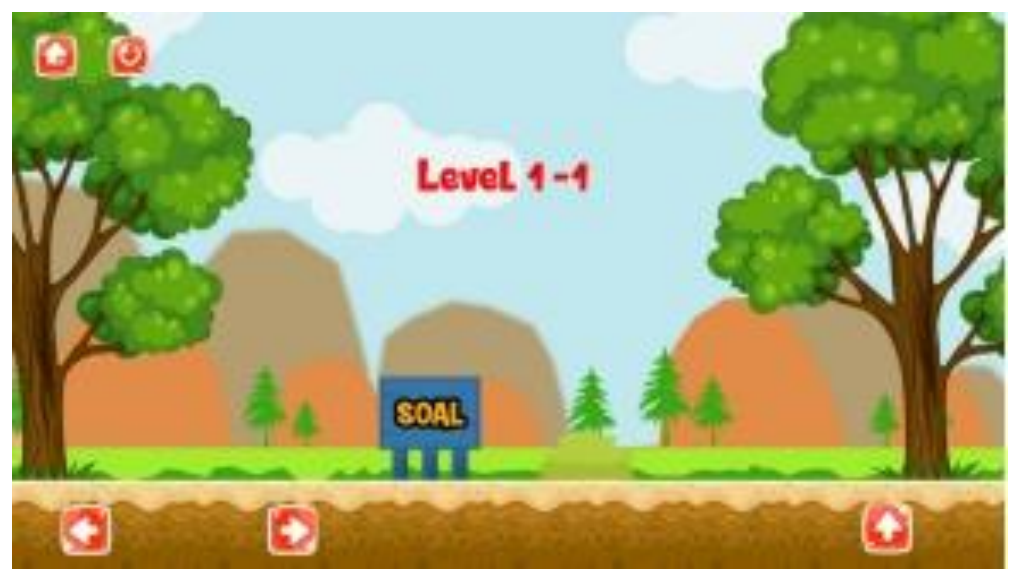

Gambar 5. Tampilan Level 1

Pada Gambar 5 di atas adalah tampilan gambar pada level 1. Dalam level tersebut terdapat 5 soal dan karakter harus melewati rintangan berduri serta menjawab soal dengan benar. Apabila soal yang dijawab benar, maka karakter akan menuju ke soal berikutnya tetapi apabila soal yang dijawab salah maka muncul tampilan anda salah dan tersedia perintah mengulang di level yang sama atau kembali ke menu utama. Dalam level ini terdapat 5 macam tombol yaitu tombol arah kiri yang digunakan untuk mundur, tombol arah kanan yang digunakan untuk maju, tombol ke atas untuk lompat, tombol home untuk kembali ke menu, dan tombol restart untuk mengulang permainan.

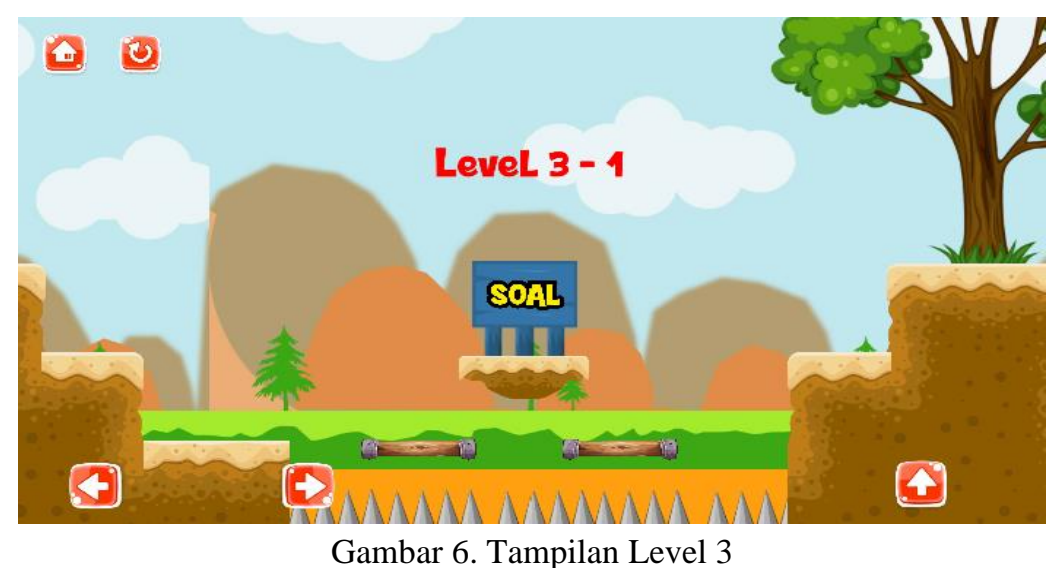

Pada Gambar 6 adalah tampilan pada level 3. Di dalam level 3 karakter harus melewati rintangan berduri, papan serta jembatan kayu. Dalam level ini terdapat 5 macam tombol yaitu tombol arah kiri yang digunakan untuk mundur, tombol arah kanan yang digunakan untuk maju, tombol ke atas untuk lompat, tombol home untuk kembali ke menu, dan tombol restart untuk mengulang permainan. 


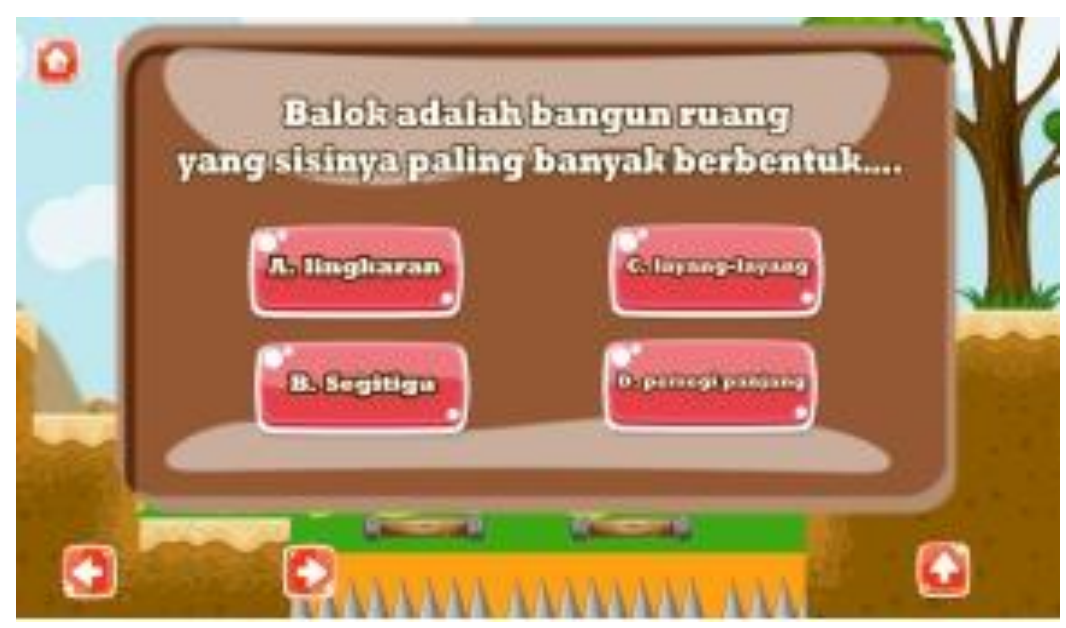

Gambar 7. Soal latihan

Pada Gambar 7 di atas adalah muncul setelah karakter sudah melewati tampilan dari soal latihan, tampilan ini akan semua rintangan.

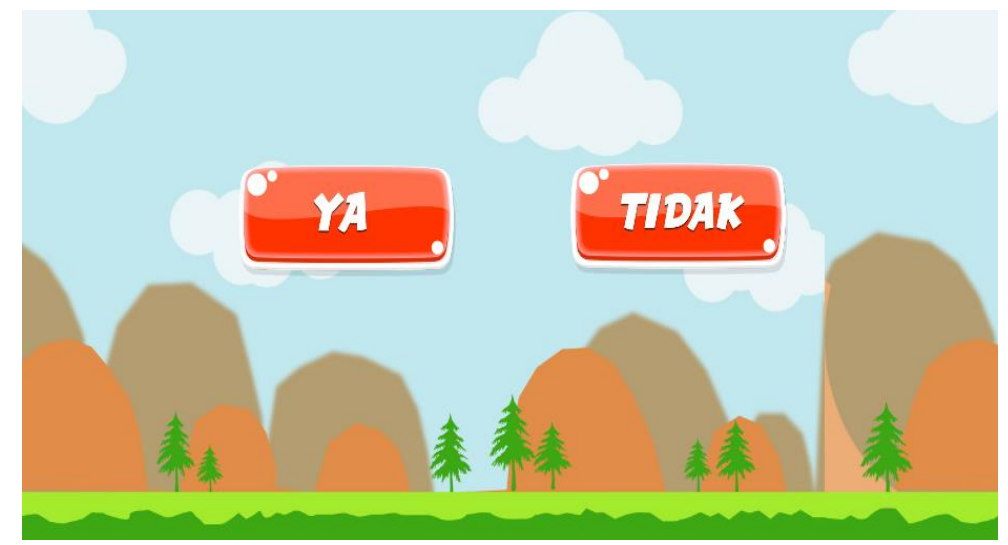

Gambar 8. Tampilan menu keluar

Pada Gambar 8 di atas merupakan tampilan dari menu keluar. Tampilan ini akan muncul ketika pemain menekan tombol keluar dan akan ada tampilan seperti gambar di atas. Jika pemain ingin keluar game, maka tekan tombol button ya dan jika tidak, maka tekan tombol button tidak. Dari proses di atas, pembuatan asset-asset game beserta komponennya telah berhasil dibuat dengan aplikasi Adobe Photoshop dan Unity.

Testing (Pengujian). Game edukasi matematika dunia kubus dan balok ini akan di uji untuk mengetahui apabila ada kesalahan. Jika semua sudah berjalan dengan baik maka proses akan lanjut ke tahap berikutnya yaitu distributions. Pada tahap pengujian dilakukan dengan dua metode yaitu pengujian alpha dan selanjutnya akan dilakukan pengujian beta.

Pengujian alpha adalah pengujian fungsi sistem secara menyeluruh atau suatu strategi pengujian perangkat lunak yang digunakan dalam pengembangan perangkat lunak. Dalam tahap ini dilakukan pengujian dengan alpha test. Hal ini dilakukan dengan tujuan untuk menemukan kasalahan fungsi program. Dari proses pengujian yang dilakukan secara berulang-ulang dapat memperoleh hasil pengujian dari game ini yang terangkum dalam tabel hasil pengujian sebagai berikut: 
Tabel 3. Pengujian alpha

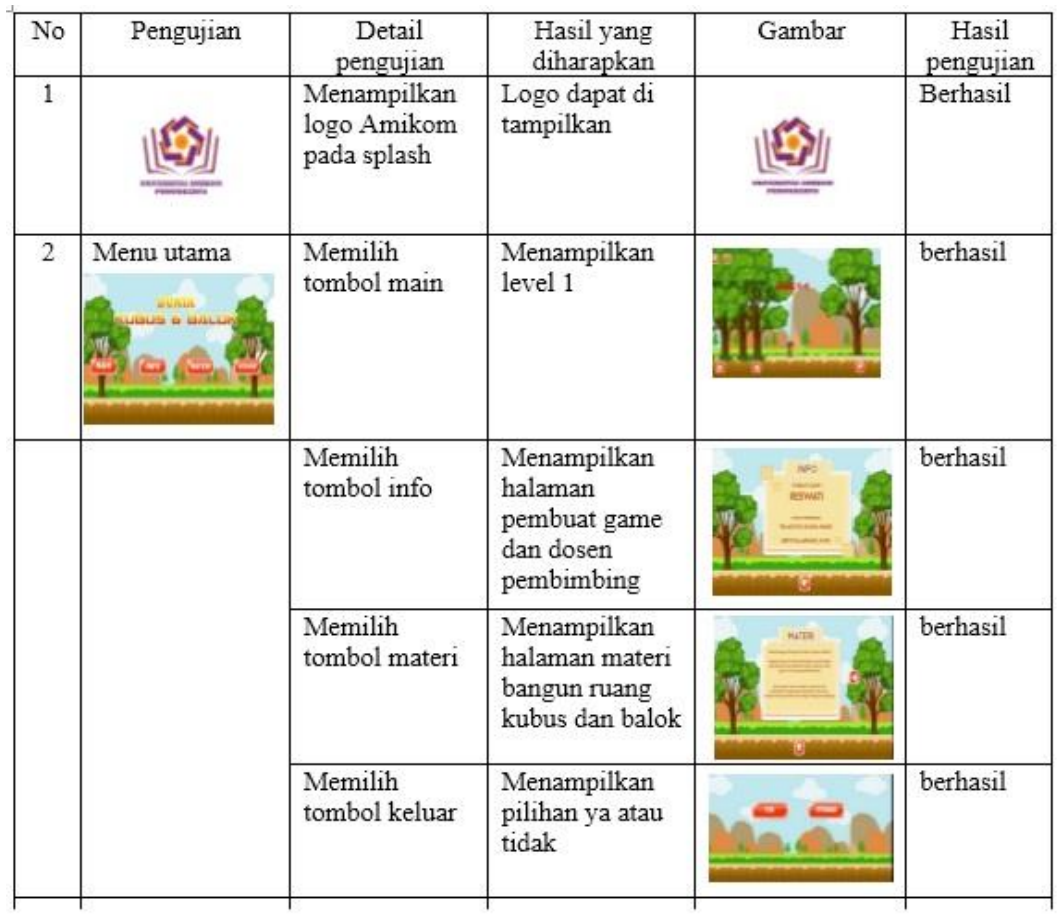

Berdasarkan dari hasil Tabel 3 pengujian alpha terhadap game edukasi matematika kubus dan balok menunjukan bahwa game edukasi matematika sesuai dengan yang diharapkan.

Beta test merupakan pengujian aplikasi untuk mengetahui respon dari responden tehadap game edukasi matematika Kubus dan balok yang telah dibuat. Pada tahap ini responden mencoba game yang telah dibuat kemudian mereka diminta untuk mengisi kuisioner yang berisi 5 pertanyaan. Kuisioner diberikan ke siswa kelas V sebanyak 30 anak. Pada penelitian ini digunakan skala likert untuk melakukan perhitungan. Menurut Sugiyono (2018), skala likert digunakan untuk mengukur sikap, pendapat dan persepsi seseorang atau kelompok orang terhadap fenomena sosial. Jawaban yang menggunakan skala likert yang dimodifikasi mempunyai dua alternatif jawaban yaitu positif dan negatif. Perhitungan skala likert menggunakan rumus sebagai berikut:

Menghitung jumlah skor dan total skor
Jumlah Skor $=\mathrm{T} \times \mathrm{P}_{\mathrm{n}}$ $T$ : Total jumlah responden $\mathrm{P}_{\mathrm{n}}$ : Pilihan angka skor likert

Menghitung interpretasi skor perhitungan untuk mengetahui skor tertinggi dan skor terendah.

$\mathrm{Y}=$ skor tertinggi likert $\times$ jumlah responden

$\mathrm{X}=$ skor terendah likert $\times$ jumlah responden

Menghitung interval skoring (I)

$$
I=\frac{100}{\text { jumlah skor }}
$$

Kategori Skor $=\frac{\text { Total Skor }}{Y} \times 100 \%$

Pengumpulan hasil tanggapan dari responden setelah mencoba game edukasi matematika bangun ruang kubus dan balok berbasis android ditunjukkan pada Tabel 4 sebagai berikut: 
Tabel 4. Hasil Tanggapan Responden

\begin{tabular}{|c|c|c|c|c|c|}
\hline \multirow{2}{*}{ Pernyataan 1 } & \multicolumn{5}{|c|}{ Kategori } \\
\cline { 2 - 6 } & SS & S & N & TS & STS \\
\hline Responden & 17 & 10 & 3 & 0 & 0 \\
\hline
\end{tabular}

Keterangan :

SS : Sangat Setuju (5)

$\mathrm{S}$ : Setuju (4)

$\mathrm{N}$ : Netral (3)

TS : Tidak Setuju (2)

STS: Sangat Tidak Setuju (1)

Menghitung jumlah skor dan total skor

Jumlah Skor $=$

Responden SS $=17 \times 5=85$

Responden $S=10 \times 4=40$

Responden $\mathrm{N}=3 \times 3=9$

Responden TS $=0 \times 2=0$

Responden STS $=0 \times 1=0$

Jadi, total skor pertanyaan $1=$

$85+40+9+0+0=134$

Menghitung interpretasi skor perhitungan

Skor tertinggi $(\mathrm{Y})=5 \times 30=150$

Skor terendah $(\mathrm{X})=1 \times 30=30$

Menghitung interval skoring (I)

$$
I=\frac{100}{5}=20
$$

Skor berdasarkan interval :

0\% $-19,99 \%=$ Sangat Tidak Setuju

$20 \%-39,99 \%=$ Tidak Setuju

$40 \%-59,99 \%=$ Netral

$60 \%-79,99 \%=$ Setuju

$80 \%-100 \%=$ Sangat Setuju

$$
\begin{aligned}
\text { Kategori skor } & =\frac{134}{150} \times 100 \% \\
& =89 \%
\end{aligned}
$$

Hasil akhir pengujian game edukasi matematika kubus dan balok dari 5 pernyataan memiliki nilai rata-rata sebagai berikut :

Rata-rata $=$

$\frac{89 \%+89 \%+86 \%+86 \%+90 \%}{5}=88 \%$

Jadi rata-rata rumus index dari 30 responden sebesar $88 \%$ dan termasuk dalam kategori sangat setuju, hal ini menunjukan bahwa aplikasi game edukasi matematika bangun ruang kubus dan balok yang dibuat menarik dan mudah digunakan oleh siswa SD Negeri 3 Tanjunganom khususnya kelas V. Dengan kata lain, game edukasi matematika ini dianggap berhasil sebagai inovasi baru pada media pembelajaran serta layak digunakan.

Distribution (Distribusi). Peneliti memilih menggunakan flaskdisk yang didalamnya terdapat file softcopy .apk dari aplikasi game edukasi matematika bangun ruang kubus dan balok. Kemudian aplikasi tersebut di instal pada android SD N 3 Tanjunganom, sehingga siswa dapat langsung menggunakan aplikasi tersebut.

\section{SIMPULAN}

Berdasarkan uraian pembahasan di atas, dapat disimpulkan bahwa telah berhasil dibuat game edukasi matematika sub materi bangun ruang kubus dan balok berbasis android. Hasil pengujian Beta test yang melibatkan 30 responden diperoleh rata-rata $88 \%$ sangat setuju, artinya bahwa aplikasi game edukasi matematika bangun ruang kubus dan balok yang dibuat menarik dan mudah digunakan oleh siswa SD Negeri 3 Tanjunganom khususnya kelas $\mathrm{V}$. 


\section{DAFTAR RUJUKAN}

Binanto, I. (2010). Multimedia Digital Dasar Teori dan Pengembangannya. Yogyakarta: CV. Andi Offset.

Nikensasi, P., Kuswardayan, I., \& Sunaryono, D. (2012). Rancang Bangun Permainan Edukasi Matematika dan Fisika dengan Memanfaatkan Accelerometer dan Physics Engine Box2d pada Android. Jurnal Teknik ITS, 255260.

Novaliendry, D. (2013). Aplikasi Game Geografi Berbasis Multimedia Interaktif (Studi Kasus Siswa Kelas IX SMPN 1 RAO). Jurnal Teknologi Informasi \& Pendidikan, 106-118.

Pramuditya, S. A., Noto, M. S., \& Purwono, H. (2018). Desain Game Edukasi Berbasis Android Pada Materi Logika Matematika. JNPM (Jurnal
Nasional Pendidikan Matematika), 165-179.

Sugiyono. (2018). Metode kualitatif dan kuantitatif $R \quad \& \quad D$. Bandung: Alfabeta.

Wibawanto, W. (2017). Desan dan Pemrograman Multimedia Pembelajaran Interaktif. Patrang Jember: Cerdas Ulet Kreatif. 